\title{
Implementasi Pendekatan Saintifik Sebagai Pembentuk Keterampilan Proses Sains Anak Usia Dini
}

\author{
Maria Melita Rahardjo \\ maria.rahardjo@uksw.edu \\ PG-PAUD, FKIP, Universitas Kristen Satya Wacana
}

The Implementation of Scientific Approach to Develop Children's Science Process Skills

\begin{abstract}
Science education for early childhood education has received considerable attention from many researchers. Even though the new Indonesian early childhood curriculum does not provide specific curriculum objectives for science lesson, the science has been integrated in the curriculum through 'pendekatan saintifik' (scientific approach). There are not many journal articles which covered this topic. Several journals mentioned the importance of this approach, some other journals tried to find best model for implementing the approach. However, very few journals discussed deeply about the implementation of that approach. Therefore, this research paper will discuss the findings of scientific approach in three early childhood schools. The descriptive qualitative approach was used in the research.. The results show that the time allocation, the number of objects provided, and teachers' questions are three important factors which affect the quality of scientific approach implementation.
\end{abstract}

Keywords: Science Education, Scientific Approach, Indonesian Early Childhood Curriculum, Kurikulum 2013

Received date: 15 April 2019

Revised date: 30 April 2019

Accepted date: 21 Mei 2019

\section{PENDAHULUAN}

Pembelajaran sains dianggap penting bagi perkembangan anak, terutama dalam mendukung perkembangan bahasa, literasi, dan numerasi. Oleh karenanya, pembelajaran sains pada anak usia dini mulai mendapat cukup banyak perhatian dalam beberapa tahun terakhir ini, terutama pembelajaran sains yang berbasis pendekatan inkuiri (Gerde, Schachter, dan Wasik, 2013; Howit, Upson, dan Lewis, 2011; Inan, Trundle, dan Kantor, 2010; Peterson and French 2008). Pembelajaran sains berbasis inkuiri disinyalir dapat berpengaruh signifikan terhadap perkembangan anak, tetapi pada praktiknya akses anak kepada pembelajaran sains yang berkualitas masih sangat minim (Early, dkk., 2010; Hanley, Tiger, Ingvarsson, dan Cammilleri, 2009; Nayfed, Brenneman, dan Gelman, 2011; Tu, 2006)

National Education Science Standards - NESS (2012) menyatakan bahwa sains sebagai inkuiri adalah lebih dari sekadar "keterampilan proses sains" seperti mengamati, menyimpulkan, atau melakukan eksperimen. Sains sebagai inkuiri melibatkan keterampilan untuk mendeskripsikan objek, menanyakan pertanyaan, membuat penjelasan, mengetes penjelasan tersebut berdasar teori yang telah ada, hingga mengkomunikasikan ide. Pada dasarnya, pendekatan inkuiri yang ada dalam NESS tersebut juga menjelaskan tentang proses sains, tetapi hal yang memunculkan pertanyaan adalah catatan awal mereka yang mengatakan bahwa "inkuiri lebih dari sekadar kemampuan proses sains". Pernyataan tersebut memang perlu untuk digali dan dipahami lebih jauh maknanya. Meskipun demikian, penelitian saya tidak bermaksud untuk mengkaji pernyataan tersebut. Penelitian dalam artikel ini mau menyoroti tentang sains sebagai proses, hal yang juga sebenarnya menjadi titik berat pendekatain inkuiri.

Pentingnya keterampilan proses sains sebenarnya juga disadari oleh pembuat kebijakan PAUD di Indonesia. Kurikulum 2013 PAUD (Kemendikbud, 2014) menetapkan tentang pendekatan saintifik sebagai karakteristik kurikulum PAUD nasional. Ini artinya bahwa pembelajaran anak usia dini seharusnya menerapkan pendekatan saintifik dalam setiap pertemuan pembelajarannya. Pendekatan saintifik hakikatnya juga merupakan pengembangan keterampilan proses sains dan juga memuat unsurunsur pendekatan inkuiri. Ada 5 tahapan dalam pendekatan saintifik kurikulum 2013 PAUD yang senada dengan unsur-unsur keterampilan proses sains atau pendekatan inkuiri, yaitu tahapan 
mengamati, menanya, mengumpulkan data, menalar, dan mengkomunikasikan. Pentingnya pendekatan saintifik dalam pengembangan literasi sains anak usia dini ditekankan dalam kurikulum nasional. Literasi sains menjadi penting untuk dipersiapkan sejak dini supaya anak-anak tersebut memiliki kemampuan proses sains yang memadai di jenjang sekolah lanjutan.

Munastiwi (2015) mengkaji tentang implementasi pendekatan saintifik pada anak usia dini (AUD). Dalam tulisannya, Munastiwi mengatakan bahwa pendekatan saintifik sangat penting untuk AUD dan mencakup 5 tahapan. Namun tulisan dalam jurnal ilmiah tersebut ternyata hanya kajian teoritis yang senada dengan yang tercantum dalam kurikulum PAUD. Tidak ada hasil penelitian tentang bagaimana implementasi pendekatan saintifik di lapang. Demikian pula tulisan Angkur (2019) yang hanya mengulang kajian teoritis tentang pentingnya pendekatan saintifik, tanpa dibarengi dengan penelitian lapangan. Mengingat pentingnya pendekatan saintifik, sebaiknya ada kajian lebih dalam tentang apakah implementasi pendekatan tersebut sudah baik atau masih mengalami berbagai kendala. Jika ada kendala, kendala apa saja yang muncul sehingga bisa dicarikan solusinya.

Demikian pula Suryana (2017), misalnya, mengembangkan model pembelajaran tematik terpadu berbasis pendekatan saintifik karena melihat bahwa penerapan pembelajaran dengan pendekatan saintifik belum sesuai proses yang benar. Meskipun demikian, Suryana tidak mendeskripsikan ketidaksesuaian apa saja yang ditemui di lapang. Demikian pula halnya Suryana tidak cukup memberikan gambaran tentang model yang dikembangkannya, serta bagaimana model pembelajaran yang dikembangkan tersebut dapat mengatasi masalah implementasi pendekatan saintifik yang tidak sesuai prosesnya.

Dari beberapa artikel ilmiah terbatas yang ditemukan tentang pendekatan saintifik, hanya ada satu penelitian yang mengkaji tentang implementasi pendekatan saintifik di sebuah lembaga TK di Yogyakarta (Utami, 2016). Lembaga TK tersebut merupakan salah satu lembaga rintisan yang mengadopsi kurikulum 2013 serta menerapkan pendekatan saintifik dalam pembelajarannya. Utami (2016) menyimpulkan bahwa implementasi pendekatan saintifik pun belum optimal. Setidaknya ada dua faktor yang menyebabkan ketidakoptimalan penerapan pendekatan saintifik dalam pembelajaran. Pertama yaitu waktu untuk pengamatan dan pengumpulan informasi yang kurang sehingga anak tidak tuntas dalam mempelajari topik yang diusung. Kedua adalah kurangnya referensi guru dalam penerapan pendekatan saintifik. Kurangnya referensi guru diduga berdampak terhadap kualitas implementasi pendekatan saintifik.

Minimnya kajian ilmiah tentang pendekatan saintifik kurikulum 2013 pendidikan anak usia dini dan kurang dalamnya pembahasan dari kajian-kajian yang adalah yang melatarbelakangi penelitian yang ini. Peneliti merasa perlu untuk mengkaji implementasi pendekatan saintifik tersebut dalam pembelajaran. Penelitian ini senada dengan penelitian Utami (2016), hanya saja berbeda pada fokus kajiannya. Penelitian Utami (2016) memiliki tiga kajian utama yaitu implementasi pendekatan saintifik, upaya penanaman kompetensi inti, dan faktor pendukung/ penghambat pendekatan saintifik. Perbedaan penelitian ini dengan penelitian yang sudah ada tersebut adalah pada fokus kajian dan jumlah subjek penelitiannya. Penelitian ini tidak dibatasi pada satu lembaga saja. Penelitian ini mengkaji tiga lembaga PAUD yang memiliki seting lingkungan dan metode pembelajaran berbeda. Pertanyaan penelitian yang ingin dijawab adalah bagaimana implementasi pendekatan saintifik dalam pembelajaran AUD di lembaga-lembaga PAUD tersebut.

\section{KAJIAN PUSTAKA}

Pendidikan sains bagi anak usia dini banyak menemui banyak pertentangan dalam pelaksanaannya. Pertanyaan-pertanyaan seperti apakah sains cocok dan tepat untuk diajarkan bagi anak usia dini banyak bermunculan, merujuk pada kenyataan bahwa orang dewasa pun tak jarang menemui kesulitan dalam memahami konsep-konsep sains. Misalnya, temuan penelitian Airlanda (2019) yang menyebutkan bahwa mahasiswa belum memiliki keterampilan proses yang memadai untuk mengambil keputusan sederhana. Meskipun banyak pertentangan,banyak peneliti meyakini bahwa pembelajaran sains sangat mungkin dan sangat penting untuk dilakukan sejak anak usia dini (Ashbrook, 2003; Eschach dan Fried, 2005; Klarisa, 2018; Mirawati dan Nugraha, 2017; Morrison, 2012; Putri, Mawardi, dan Diana, 2017; Ravanis, 2017; Sikder dan Fleer, 2014)

Pembelajaran sains pada hakikatnya mencakup dua dimensi yaitu sains sebagai proses (keterampilan proses sains) dan sains sebagai produk. Padilla (1990) mengelompokkan keterampilan 
proses sains menjadi keterampilan proses sains dasar dan keterampilan proses sains terintegrasi. Keterampilan proses sains dasar meliputi pengamatan, pengukuran, pengambilan kesimpulan, komunikasi, klasifikasi, dan prediksi. Keterampilan proses sains teritegrasi meliputi pengontrolan variabel, penetapan definisi operasional, penyusunan hipotesis, penginterpretasian data, eksperimen, dan penyusunan model. Pengelompokan keterampilan sains oleh Padilla tersebut banyak dirujuk oleh peneliti-peneliti lain yang mengkaji tentang keterampilan proses sains.

Selanjutnya dimensi sains sebagai produk sebenarnya adalah informasi atau pengetahuan (produk) yang didapat dari serangkaian proses sains yang dilakukan (hasil mengamati, menganalisa, mencoba). Pengetahuan atau produk sains dikelompokkan menjadi empat cabang yaitu ilmu fisika, ilmu kimia, ilmu bumi dan angkasa, dan ilmu biologi.

Pentingnya pendidikan sains bagi anak usia dini tampaknya juga disadari oleh para pemangku kebijakan di Indonesia. Oleh karena itu, meskipun kurikulum pendidikan anak usia dini (kurikulum 2013) tidak memiliki bagian khusus yang membahas tentang kurikulum pembelajaran sains, pendekatan saintifik ditetapkan untuk menjadi ciri khas kurikulum PAUD. Kurikulum 2013 pada hakikatnya menitikberatkan pada pengembangan sains sebagai proses atau yang disebut dengan keterampilan proses sains. Buku pedoman yang diterbitkan Kemendikbud sebagai pelengkap dokumen kurikulum membahas cukup detail contoh-contoh penerapan implementasi keterampilan proses sains dalam proses pembelajarannya.

Dalam kurikulum 2013, pendekatan saintifik didefinisikan sebagai sebuah pendekatan atau membangun pola pikir dan daya nalar anak melalui lima tahapan. Kelima tahapan tersebut adalah mengamati, menanya, mengumpulkan informasi, menalar, dan mengomunikasikan.

1. Mengamati, menanya, dan mengumpulkan informasi

Tahap paling awal dalam pendekatan saintifik adalah mengamati, dilanjutkan dengan menaya, dan mengumpulkan data. Penulis menyatukan ketiga tahapan ini menjadi satu bagian pembahasan karena pada dasarnya, mengamati dan menanya adalah bagian dari keterampilan proses untuk mengumpulkan informasi. Di kurikulum PAUD penjelasan tentang perbedaan ketiganya tidak benarbenar jelas dibahas, malah ada kecenderungan tumpang tindih. Sebagai contoh, di keterangan pendekatan sains "mengamati" tertulis "mendorong anak untuk mengamati dari berbagai sudut/ arah bagian-bagian pohon pisang". Demikian pula di keterangan pendekatan sains "mengumpulkan informasi" tertulis "mengamati pohon pisang dengan pengamatan mendalam". Kedua penjelasan tersebut tidak menampakkan batas beda yang dapat memperjelas definisi tahapan "mengamati" maupun tahapan " mengumpulkan informasi".

Ketidakjelasan perbedaan antara tahapan tersebut sebenarnya wajar, karena sebenarnya mengamati merupakan salah satu cara dari tahap mengumpulkan data. Pengumpulan data atau informasi bisa dilakukan dengan berbagai cara seperti bertanya (menanya), mengamati dengan lima indra, dan melakukan pengukuran. Pengamatan menggunakan panca indra akan cenderung menghasilkan data kualitatif. Selanjutnya, untuk mendapat data dengan derajat yang lebih terukur, pengamatan dapat diekstensi dengan pengukuran. Sebagai contoh, anak yang mengamati dua pohon pisang akan bilang pohon yang satu lebih pendek dibanding pohon lainnya. Tetapi jika pohon tersebut memiliki tinggi yang hampir sama, maka diperlukan pengukuran dengan menggunakan meteran supaya benar-benar bisa mengatakan bahwa pohon satu lebih tinggi dibanding pohon yang lain.

2. Menalar dan mengkomunikasikan

Tahapan pendekatan saintifik setelah mengumpulkan informasi adalah menalar. Dalam kamus bahasa indonesia, berpikir nalar diartikan sama dengan berpikir logis. Dalam berbagai kajian, pemikiran logis sering dijelaskan dengan contoh premis-premis. Premis A, B, dan C diketahui, maka dapat dibuat sebuah kesimpulan. Artinya, meskipun informasi yang diterima hanya sebagian-sebagian, dapat dibuat sebuah kesimpulan. Kesimpulan bisa jadi salah, bisa jadi benar setelah mengalami pengujian. Itulah yang disebut prediksi atau hipotesa. Jadi, pendekatan saintifik "menalar" dapat diamati ketika anak memprediksi sesuatu, atau menyimpulkan sesuatu setelah melalui proses perolehan data yang cukup.

Tahapan menalar tidak dapat berdiri sendiri. Ketika anak menalar, maka anak perlu mengkomunikasikan penalarannya supaya guru dapat mengevaluasi proses belajar anak. Dengan komunikasi, anak dapat mengungkapkan ide dan hasil belajarnya. Anak juga bisa mendapat tanggapan dan umpan balik yang semakin memperkaya proses belajarnya. Komunikasi dapat dilakukan dalam bentuk lisan, tulisan, maupun hasil karya. Bentuk komunikasi menyesuaikan dengan tahap perkembangan anak. Bagi anak yang belum dapat memaparkan data observasi dan penalaran melalui 
tulisan, media komunikasi lisan dan hasil karya dapat menjadi alternatif pilihan. Keterampilan proses sains berkontribusi terhadap perkembangan pemikiran logis seorang anak (Sriningsih, 2018).

\section{METODE PENELITIAN}

Penelitian ini menggunakan pendekatan penelitian deskriptif kualitatif. Menurut Sanjaya (2013) penelitian dekriptif adalah penelitian yang berusaha menjelaskan fakta dan sifat suatu populasi tertentu secara sistematis dan faktual. Pendekatan penelitian kualitatif tidak dimaksudkan untuk mengeneralisasi data hasil temuan. Pendekatan kualitatif digunakan untuk menggali secara dalam sebuah fakta atau fenomena yang ingin diteliti (Sugiyono, 2017).

Penelitian dilaksanakan selama rentang waktu 3 bulan sejak Januari hingga Maret 2019. Ada tiga sekolah yang menjadi partisipan penelitian. Ketiganya dipilih secara khusus karena masing-masing sekolah memiliki ciri khas yang menjadi dasar pemilihan sekolah. Sekolah pertama yaitu sekolah M memiliki penataaan lingkungan belajar dan metode pembelajaran klasikal. Sekolah kedua yaitu sekolah L merupakah sekolah yang memiliki pembagian pembelajaran berdasar subjek khusus. Sekolah L memiliki alokasi waktu khusus untuk pembelajaran sains. Terakhir, sekolah K merupakan sekolah yang memiliki penataan pembelajara model sentra. Sekolah ini baru mengadopsi model sentra dalam kurun waktu 6-12 bulan terakhir setelah menerima pelatihan tentang kurikulum 2013.

Instumen penelitian yang digunakan untuk pengambilan data adalah rekaman video pelaksanaan pembelajaran di tiga sekolah partisipan, dilengkapi dengan data pendukung berupa catatan observasi dan dokumen RPPH. Data-data yang telah dikumpulkan akan dianalisa menggunakan teknik editing, coding, tabulasi data, dan analisa data.

Peneliti menggunakan beberapa teknik pemeriksaan keabsahan data (Moleong, 2009) seperti keterlibatan peneliti, triangulasi data, dan pengecekan anggota. Dalam penelitian, uji keabsahan data umumnya meliputi uji validitas dan uji reliabilitas. Validitas merujuk pada ketepatan antara data yang diperoleh dalam penelitian dengan data yang dilaporkan oleh peneliti. Reliabilitas merujuk pada konsistensi atau ketepatan data dari waktu ke waktu (Sugiyono, 2017).

\section{HASIL PENELITIAN DAN PEMBAHASAN}

Penelitian dilaksanakan di tiga lembaga PAUD yang berbeda. Ketiga lembaga PAUD memiliki bentuk model penataan lingkungan belajar yang berbeda-beda. Berikut ini adalah cuplikan pembelajaran dalam satu hari di tiga sekolah tersebut.

Tabel 1. Hasil Observasi Pelaksanaan Pembelajaran Sains di Tiga Sekolah

\begin{tabular}{|c|c|c|c|}
\hline & Sekolah M & Sekolah L & Sekolah K \\
\hline Lokasi Observasi & Kelompok Bermain & Kelompok Bermain & TK B \\
\hline Jumlah guru & 1 guru & 1 guru & 1 guru \\
\hline $\begin{array}{l}\text { Jumlah anak dalam } \\
\text { satu kelas }\end{array}$ & 16 anak & 10 anak & 16 anak \\
\hline Rentang usia anak & 3-4 tahun & 3-4 tahun & 5-6 tahun \\
\hline $\begin{array}{l}\text { Menggunakan } \\
\text { pendekatan tematik }\end{array}$ & Ya: Kencur & Tidak & Ya: Kentang \\
\hline $\begin{array}{l}\text { Penataan } \\
\text { lingkungan belajar }\end{array}$ & $\begin{array}{l}\text { Satu kelas yang ditata } \\
\text { dengan seting klasikal. }\end{array}$ & $\begin{array}{l}\text { Satu kelas yang ditata } \\
\text { dengan seting klasikal }\end{array}$ & $\begin{array}{l}\text { Satu kelas yang setiap } \\
\text { hari diubah seting } \\
\text { sentranya. }\end{array}$ \\
\hline $\begin{array}{l}\text { Implementasi } \\
\text { Pembelajaran }\end{array}$ & $\begin{array}{l}\text { 1. Setelah rutinitas } \\
\text { pagi (berdoa dan } \\
\text { bernyanyi bersama, } \\
\text { anak-anak duduk di } \\
\text { kursi masing- } \\
\text { masing dan } \\
\text { menghadap ke arah } \\
\text { guru yang berdiri di } \\
\text { depan kelas. }\end{array}$ & $\begin{array}{l}\text { 1. Setelah rutinitas } \\
\text { pagi (berdoa dan } \\
\text { bernyanyi dalam } \\
\text { lingkaran), guru } \\
\text { membawa nampan } \\
\text { berisi betadine, } \\
\text { vitacimin, sendok, } \\
\text { dan gelas plastlik. } \\
\text { 2. Guru mengajak }\end{array}$ & 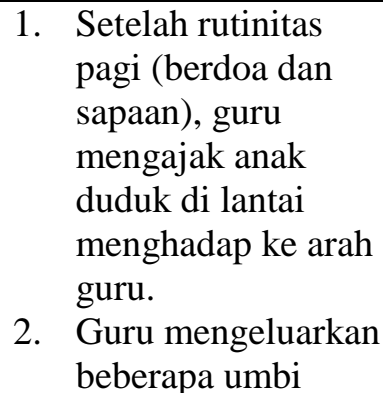 \\
\hline
\end{tabular}




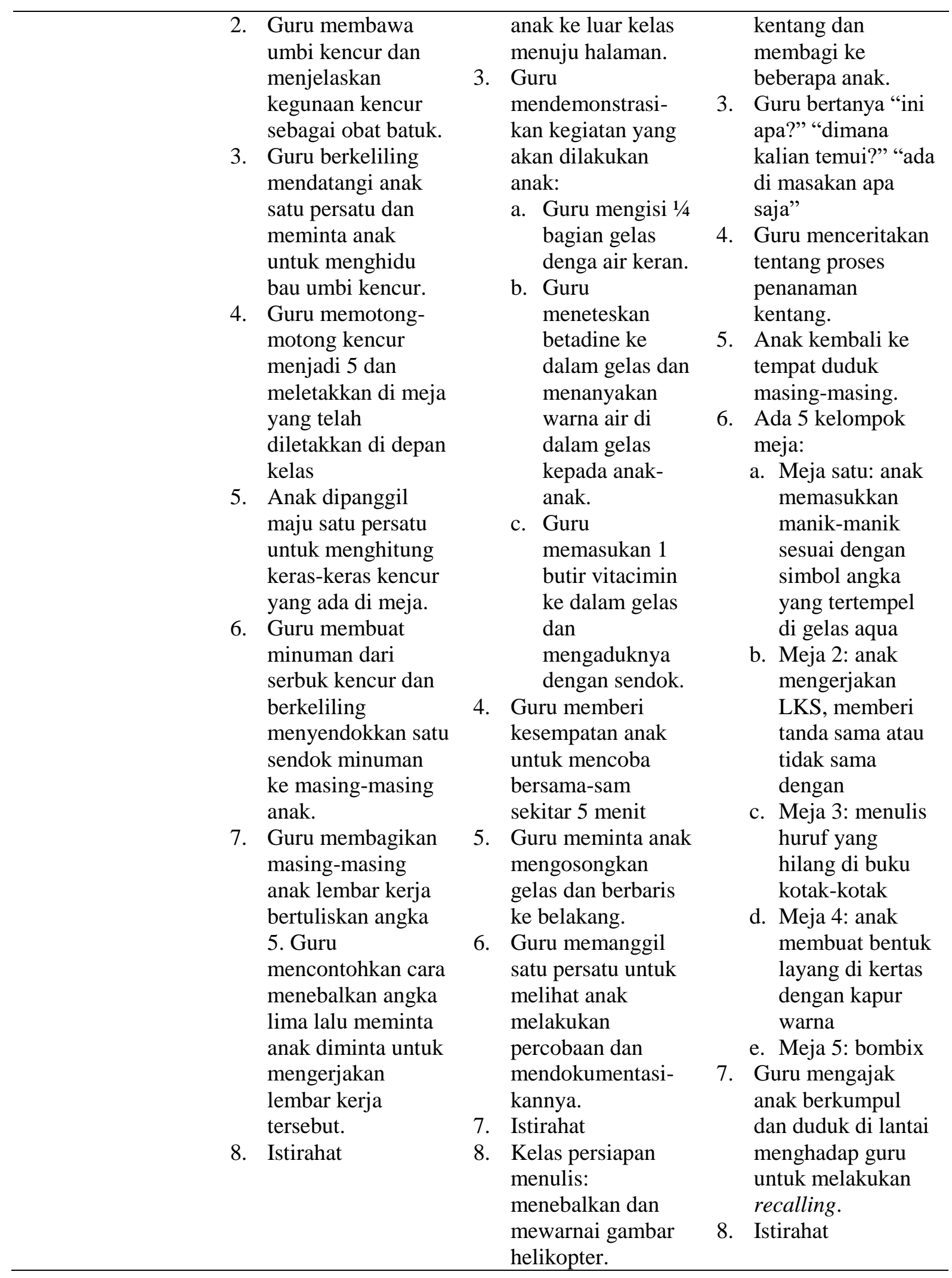

Sekolah M menggunakan model penataan lingkungan belajar klasikal. Rahayu (2015) menyebutkan bahwa bentuk kelas klasikal adalah bentuk kelas dimana semua kursi ditata menghadap guru. Hal ini nampak ketika guru sekolah $\mathrm{M}$ meminta semua anak untuk menghadap ke arahnya dan mendengarkan penjelasannya. Rahayu (2015) juga menyebutkan bahwa metode pembelajaran yang digunakan di kelas klasikal bertujuan supaya anak melakukan hal yang sama rata. Ini pula yang nampak dalam kegiatan pembelajaran sekolah M. Guru menyiapkan media pembelajaran yang seragam untuk 
semua anak. Sebagai contoh, dalam kegiatan belajar menebalkan angka lima, guru menyiapkan lembar kerja dan membagi ke masing-masing anak. Anak-anak memulai pekerjaan dalam waktu yang bersamaan meskipun biasanya waktu selesai berbeda-beda. Untuk mengantisipasi waktu selesai yang berbeda-beda, guru biasanya menyiapkan dua sampai tiga kegiatan di model klasikal ini. Jika anak telah selesai mengerjakan satu kegiatan, maka anak akan bisa melanjutkan ke pekerjaan selanjutnya. Selanjutnya, jika anak telah selesai mengerjakan ketiga aktivitas yang ada sedangkan ada temantemannya yang belum selesai, mereka bisa bermain bebas di dalam kelas dengan memanfaatkan beragam media permainan yang tersedia di kelas.

Sekolah L juga menggunakan penataan lingkungan belajar klasikal, sama seperti sekolah M. Bedanya, sekolah L tidak menggunakan pendekatan tematik. Artinya, tidak ada tema tertentu yang dibahas pada satu hari tersebut. Sekolah ketiga menggunakan pendekatan kurikulum berbasis subjek mata pelajaran (subject-centered curriculum). Artinya, pembagian kegiatan ini dilakukan dengan berfokus pada aspek perkembangan terentu dan konsep tertentu. Sebagai contoh, pembelajaran inti hari senin difokuskan untuk pengembangan moral dan motorik halus, hari selasa difokuskan untuk mengembangkan keterampilan sains dan persiapan menulis, dan seterusnya. Materi kegiatan di setiap kegiatan inti bebas dan tidak terikat tema.

Sekolah K menggunakan penataan belajar model sentra. Setiap hari anak-anak belajar di sentra yang berbeda-beda. Dalam sentra, guru menyiapkan 4-5 aktivitas belajar yang telah ditata secara bersamaan. Selanjutnya, jumlah anak di kelas akan dibagi sesuai dengan jumlah aktivitas yang ada. Pada hari pengambilan data, sentra yang dipakai adalah sentra persiapan. Jumlah anak di kelas 20 dan jumlah kegiatan yang dipersiapan guru ada lima. Anak dibagi menjadi lima kelompok dan per kelompoknya empat anak. Masing-masing kelompok menempati lima area kegiatan belajar yang telah dipersiapkan guru. Setelah selesai melakukan kegiatan di sebuah area, maka anak bebas berotasi ke meja kerja lain sampai semua aktivitas belajar yang disiapkan guru dilakukan semua oleh anak. Pada saat rotasi, anak tidak perlu menunggu setiap anggota kelompoknya selesai semua. Secara mandiri dan individual anak boleh berotasi selama area kerja lain ada tempat yang kosong. Pembagian kelompok hanya untuk membagi anak ke area kerja secara merata di saat awal mulai kegiatan.

Untuk kepentingan penelitian pengamatan di sekolah U dilakukan pada hari selasa karena fokus pengembangan pada keterampilan sains. Hal yang akan diamati pada pembelajaran sains tersebut adalah penggunaaan pendekatan saintifik. Untuk sekolah $\mathrm{M}$ dan sekolah S hari pengamatan tidak dialokasikan hari khusus karena kedua sekolah tersebut sudah memakai acuan kurikulum 2013 sehingga seharusnya setiap hari memakai tema dan pendekatan saintifik.

Dari hasil pengamatan, pembelajaran dengan penataan sentra sebenarnya tidak terlalu berbeda dari penataan model klasikal. Pada akhirnya semua anak diharuskan menyelesaikan kelima kegiatan belajar yang diberikan guru. Hanya saja, anak memiliki derajat kebebasan yang lebih dibanding yang model klasikal. Anak bebas memilih untuk mengerjakan kegiatan yang disukai terlebih dahulu.

\section{IMPLEMENTASI PENDEKATAN SAINTIFIK}

Berikut ini adalah analisa implementasi pendekatan saintifik pada ketiga sekolah yang diamati. Kesimpulan dan rekomendasi akan diberikan di bagian akhir.

Pengamatan yang dilakukan di tiga sekolah menunjukkan bahwa ketiga sekolah sudah berusaha memfasilitasi proses pengamatan anak. Guru sekolah $\mathrm{M}$ membawakan anak umbi kencur bukan hanya gambar umbi kencur. Guru sekolah K membawakan umbi kentang bukan hanya gambar kentang. Guru sekolah L membawakan betadine dan vitamin $\mathrm{C}$ supaya anak bisa langsung melakukan percobaan bukan hanya menonton di media layar. Tindakan guru tersebut menunjukkan upaya guru memfasilitasi keterampilan proses pengamatan anak.

Umbi kentang atau umbi kencur asli tentu lebih baik daripada sekadar gambarnya. Meskipun mengamati gambar juga merupakan kegiatan mengamati, tetapi benda nyata tiga dimensi tentu akan menghasilkan derajat pengamatan yang berbeda dengan gambar dua dimensi. Hal tersebut sesuai dengan berbagai kajian mengatakan bahwa alat dan bahan terbaik untuk pembelajaran anak usia dini adalah benda nyata. Hal ini sesuai dengan tingkat perkembangan anak usia dini yang sedang kemampuan pikir abstraknya masih dalam tahap awal. Selain itu, benda nyata juga mampu menstimulasi perkembangan sensori anak. Interaksi dengan benda nyata membuat anak mengaktifkan semua sensorinya. 
Berkaitan dengan pendekatan saintifik, penggunaan benda nyata tiga dimensi akan menghasilkan derajat pengamatan yang berbeda dengan media dua dimensi. Gambar dua dimensi hanya mengaktivasi satu indra, yaitu indra penglihatan. Terlebih lagi, anak yang belum puya pengalaman nyata dengan benda asli yang ada di gambar bisa jadi memiliki interpretasi yang berbeda. Misalnya, ketika anak mengamati gambar sapi, keterbatasan visualisasi abstrak anak bisa jadi menghambat pemahaman anak akan empat kaki sapi asli menjadi hanya dua kaki sapi di gambar. Terlebih lagi jika gambar sapi tersebut adalah gambar tunggal, maka anak juga akan terhambat dalam memahami ukuran sapi karena tidak ada gambar benda pembanding di gambar tersebut. Sebaliknya, penggunaan benda nyata bisa menstimulasi hampir kesemua indra anak. Misal dengan mengamati sapi secara langsung, anak bisa melihat ukuran nyatanya, detail bagian-bagian sapi yang pasti berbeda dengan gambar. Selain mata, indra penciuman, indra peraba, indra pendengaran juga terstimulasi. Pada akhirnya, data yang didapat melalui proses mengamati sapi secara langsung juga tentunya akan berbeda dengan data yang didapat melalui proses mengamati gambar sapi. Itulah mengapa dalam pembelajaran sains, aktivitas yang melibatkan benda nyata selalu menjadi rekomendasi pembelajaran (Duschl, Shouse, dan Schweingruber, 2008)

Ketiga lembaga PAUD yang menjadi partisipan penelitian telah menggunakan benda nyata dalam pembelajaran mereka. Guru sekolah M membawa umbi kencur asli, guru sekolah K membawa beberapa umbi kentang asli, dan guru sekolah L juga menyediakan alat bahan sejumlah anak sehingga semua dapat bereksperimen secara mandiri. Dari segi jumlah, peneliti mengamati bahwa jumlah alat bahan menentukan kualitas implementasi pendekatan saintifik. Pada sekolah M, jumlah umbi kencur yang disediakan guru hanya dua untuk enam belas siswa. Meskipun umbi tersebut benda nyata, anak tidak mendapat kesempatan berinteraksi dengan umbi tersebut karena jumlahnya yang sedikit. Anak duduk di tempatnya dan menanti guru berkeliling mendekatkan umbi kencur ke hidung mereka untuk dihidu. Kesempatan menghidu pun tak lebih dari 3 detik.

Selain indra penciuman, anak juga sebenarnya diberi kesempatan mengamati menggunakan indra penglihatannya. Mereka melihat dari tempat duduk masing-masing ketika guru menunjukkan umbi kencur dari depan kelas. Namun demikian, melihat dari kejauhan dengan mengamati umbi kencur di depan meja masing-masing tentu saja berbeda. Jika umbi kencur diletakkan di sebuah mangkuk di depan masing-masing anak, tentu anak-anak punya kesempatan untuk mengamati dengan lebih baik. Mereka bahkan akan menggunakan indra perabanya saat memegang tekstur kencur. Jika umbi kencur lebih dari satu jumlahnya dan berada dalam jangkauan mereka, mereka dapat mengamati tekstur umbi dengan lebih baik. Siswa bahkan bisa melihat bahwa antar umbi satu dengan yang lain juga memiliki perbedaan maupun persamaan. Persamaan warna, perbedaan panjang, perbedaan lekukan, dan sebagainya.

Umbi kencur yang berada dalam jangkauan anak dan dalam jumlah yang cukup juga memperbaiki kualitas observasi menggunakan indra penciuman dan perasanya. Anak bisa punya waktu cukup untuk menghidu bau umbi. Bisa jadi umbi satu dengan yang lain memiliki intensitas bau yang berbeda. Mereka juga dapat mencuil kulit kencur dan merasakan rasa kencur asli. Jika ingin ditambah dengan media minuman kencur, guru juga bisa menyediakan gelas kecil-kecil di hadapan masingmasing anak. Anak pun bisa merasakan apa beda umbi kencur asli dengan minuman kencur olahan pabrik.

Di sekolah K, kesediaan jumlah umbi kentang sudah lebih banyak dibanding sekolah M. Guru membawa sekitar lima umbi kentang, namun jumlah ini juga tak mencukup jumlah anak dalam kelas yang berjumlah 16 siswa. Posisi duduk siswa lebih dekat dengan guru dibanding di sekolah $\mathrm{M}$. Meskipun demikian, tidak semua siswa memiliki waktu pengamatan yang memadai karena umbi kentang harus diedarkan bergantian. Pertanyaan yang dilontarkan guru juga bukan pertanyaan yang memancing keterampilan proses sains "mengamati" dan "menanya". Pertanyaan lebih bersifat tertutup (Widodo, 2006), artinya pertanyaan yang menyediakan kesempatan jawaban terbatas. Contoh pertanyaan tertutup yang ditanyakan guru antara lain "Biasanya kalian melilhat kentang di masakan apa?"dan "Siapa yang suka makan kentang?". Setelah itu, walaupun anak sedang memegang umbi kentang, guru memberikan penjelasan tentang bagaimana cara pak tani menanam umbi kentang tersebut.

Dari pengalaman belajar di atas, pendekatan saintifik mengamati dan menanya juga tidak terlaksana secara optimal. Waktu yang digunakan guru dan murid mempelajari tentang umbi kentang adalah sekitar 15 menit. Selama 15 menit tersebut proses mengamati dilakukan dengan menggunakan 
beberapa umbi kentang yang diedarkan bergantian. Tidak ada anak yang menanya. Percakapan yang terjadi antara lain pertanyaan dari guru, jawaban dari anak, dan penjelasan dari guru. Dengan demikian, sama seperti sekolah M, tidak ada proses menanya yang berasal dari anak.

Di sekolah L, alat bahan yang disediakan sudah sejumlah anak. Di awal kegiatan, guru mendemonstrasikan langkah kerja. Lalu setiap anak diberi kesempatan mencoba secara bersamaan selama 5 menit. Setiap anak dapat mengisikan air ke gelas masing-masing, meneteskan betadine ke air dalam gelasnya, dan memasukan vitamin $\mathrm{C}$ ke dalam gelas lalu mengaduknya. Setelahnya, anak-anak diminta mundur mengantri untuk kemudian satu persatu anak bisa mencoba kembali langka kerja dari awal pengisian air ke gelas, hingga akhir perubahan warna menjadi putih keruh. Saat anak mencoba satu persatu, guru membantu dengan instruksi seperti "sekarang diteteskan", "tambah lagi", "aduk", dan instruksi lain terkait langka kerja sambil mengambil gambar tiap anak.

Dengan alat bahan yang mencukupi jumlahnya, masing-masing anak dapat mengamati proses perubahan warna air dari coklat/ oranye menjadi bening keruh. Meskipun demikian, tidak pula nampak adanya pertanyaan dari anak. Mereka cenderung diam sambil melakukan langkah kerja yang telah didemonstrasikan di awal. Tidak muncul pertanyaan seperti "mengapa kok warna coklat di air bisa hilang?" Hal tersebut bisa jadi karena waktu yang digunakan untuk berinteraksi dengan alat bahan sangat terbatas. Meskipun masing-masing anak memiliki alat dan bahan untuk bekerja sendiri, waktu yang diberikan untuk anak bermain dan bereksperimen juga tidak banyak. Mereka masih sedang dalam tahap mengamati, namun instruksi guru untuk mengosongkan gelas dan berbaris di belakang dan menunggu dipanggil satu persatu telah memutus proses pengamatan mereka. Selanjutnya, ketika anak dipanggil untuk mencoba satu persatu, waktu yang diberikan juga tidak banyak. Anak diharapkan melakukan satu set prosedur dari awal sampai akhir sesuai yang diinstruksikan, lalu diambil gambarnya. Jika sudah melakukan satu set rangkaian prosedur dan diambil gambarnya, anak diminta menepi dan bergantian dengan anak selanjutnya. Anak tidak memiliki waktu untuk mengesplorasi berbagai kemungkinkan yang ada seperti "apa yang terjadi jika vitamin $\mathrm{C}$ yang dimasukkan adalah butiran yang sangat kecil", "apa yang terjadi jika kita tidak mengaduk vitamin C-nya", apa yang terjadi jika saya meneteskan satu botol penuh betadine", dan sebagainya. Fokus guru yang lebih cenderung pada pengambilan gambar anak telah mereduksi kualitas pengamatan dan mengeliminasi pertanyaanpertanyaan dari anak yang mungkin timbul seandainya mereka memiliki waktu cukup untuk bereksperimen dengan alat dan bahan yang ada.

Dari ketiga sekolah yang ada, dapat kita simpulkan bahwa pendekatan saintifik untuk tahapan mengumpulkan informasi lebih banyak dilakukan melalui pengamatan. Belum ada dari ketiga sekolah yang siswanya aktif bertanya tentang materi atau bahan pembelajaran. Beberapa faktor penyebab antara lain, waktu interaksi dengan materi yang kurang, jumlah bahan yang tidak sesuai anak, dan kurangnya provokasi dari guru sehingga tidak timbul minat tanya dari anak.

Dari ketiga sekolah yang diamati, tahap menalar dan mengkomunikasikan belum muncul di ketiganya. Di sekolah M, tidak nampak anak yang mengkomunikasikan penalarannya. Tidak ada proses dimana anak dapat menyampaikan apa yang telah mereka pelajari tentang kencur. Beberapa hal yang disinyalir menjadi penyebabnya adalah karena waktu pengamatan yang kurang, dan tidak tersedianya media untuk mengkomunikasi apa yang mereka pelajari. Meskipun guru telah membawa umbi kencur, tetapi jumlah kecukupan umbi dan metode yang digunakan guru telah mengurangi kualitas pengamatan yang dilakukan oleh anak. Anak tidak memiliki waktu dan bahan yang cukup untuk melakukan pengamatan, sehingga tidak muncul bentuk komunikasi seperti pertanyaan, komentar hasil nalar, maupun komentar tentang hal yang dipelajari.

Selain itu, guru juga tidak menyediakan media yang dapat menjadi sarana komunikasi hasil belajar anak. Seandainya guru menyediakan kertas gambar dan alat gambar, clay atau dough, plastisin, atau aneka loose parts lalu meminta anak mengkomunikasikan hal-hal yang telah mereka pelajari melalui media tersebut, maka tahap komunikasi dalam pendekatan saintifik dapat terakomodasi dalam pembelajaran anak.

Di sekolah L, tidak pula nampak adanya tahapan "komunikasi" dalam pembelajaran sains mereka. Kemungkinan penyebabnya sama dengan pembelajaran di sekolah M. Pada tahap pelaksanaan percobaan/ eksperimen betadine dan vitamin C, anak tidak memiliki waktu yang cukup untuk mengekplorasi alat bahan yang ada. Pelaksanaan percobaan dikontrol cukup ketat oleh guru melalui instruksi bertahap. Anak tidak memiliki kesempatan untuk bereksperimen dengan jumlah tetesan, besaran vitamin $\mathrm{C}$, volumen air, dan jumlah adukan. Fokus guru adalah agar anak-anak dapat 
melakukan langkah kerja sesuai instruksi sehingga dihasilkan produk seperti yang direncanakan guru (warna coklat di air hilang karena reaksi dengan vitamin C).

Selain kurangnya waktu anak untuk berinteraksi dengan alat bahan yang ada, guru juga tidak memberi kesempatan anak untuk mengkomunikasikan hasil pembelajaran mereka melalui berbagai media. Demikian pula guru tidak menanyakan kembali apa yang telah dipelajari anak melalui kegiatan sains. Setelah setiap anak dipanggil satu persatu untuk melakukan prosedur kerja dan diambil fotonya, guru tidak mengadakan recalling atas kegiatan sains yang telah dilakukan. Kegiatan selanjutnya adalah mewarnai helikopter dan tidak berhubungan dengan kegiatan sains yang telah dilaksanakan sebelumnya. Kegiatan sains dianggap telah selesai dan pembelajaran dilanjutkan dengan kegiatan lain yang tidak berhubungan sama sekali.

Hal yang sama sebenarnya juga terjadi di sekolah M. Pendekatan saintifik untuk mempelajari umbi kencur juga sebenarnya terputus dan tidak didukung oleh kegiatan selanjutnya. Setelah anak-anak mempelajari umbi kencur, guru melanjutkan kegiatan pembelajaran dengan lembar kerja menebalkan angka lima. Sebenarnya, jika guru ingin supaya anak belajar angka lima, guru dapat mengintegrasikan pembelajaran tersebut ke dalam tema umbi kencur. Misalnya, anak bisa diminta membuat umbi kencur dari clay atau dough sebagai bentuk komunikasi visual hasil belajar mereka tentang umbi kencur. Selanjutnya ketika anak membuat umbi kencur, guru bisa mengintegrasikan pembelajaran angka lima dengan cara meminta anak -membuat umbi kencur sebanyak jumlah bilangan tertentu. Umbi-umbi kencur buatan dari clay ataua dough bahkan kemudian bisa menjadi bahan untuk bermain jual beli di kegiatan bermain peran. Kegaiatan jual beli tentunya akan terkait erat dengan angka. Dengan proses pembelajaran yang masih mengintegrasikan umbi kencur dalam kegiatan selanjutnya, nak-anak punya cukup watu untuk melakukan pengamatan lebih, dan dengan demikin anak-anak juga punya waktu untuk menalar apa yang sedang dipelajarinya. Selanjutnya jika tahapan proses pengamatan dan penalaran dilalui dengan baik, maka anak dapat mengkomunikasikannya.

Hal serupa juga terjadi di sekolah K. Pendekatan saintifik dilakukan untuk mempelajari umbi kentang. Meskipun demikian, tidak nampak tahapan menalar dan mengkomunikasikan hasil belajar tentang umbi kentang. Pembelajaran umbi kentang hanya berlangsung selama 20 menit. Selanjutnya, anak-anak masuk ke sentra persiapan dan megerjakan lima macam kegiatan yang telah disediakan guru. Kelima macam kegiatan tersebut tidak ada hubungannya dengan umbi kentang yang telah mereka pelajari sebelumnya. Dengan demikian komunikasi yang terjadi selama kegiatan bukanlah komunikasi tentang umbi kentang melainkan tentang lembar kerja yang sedang mereka kerjakan. Pembelajaran tentang umbi kentang melalui pendekatan saintifik hanya berlangsung selama 20 menit pertama di awal pemmbelajaran. Selama 20 menit tersebut, komunikasi yang dilakukan anak terhadap guru hanyalah sebatasa jawaban pertanyaan yang diberikan guru. Contohnya, ketika guru bertanya "Apa kalian pernah makan kentang?" Maka anak-anak menjawab "Pernah.". Kemudian guru berntanya lagi "Kalian menemukan kentang di masakan apa saja?". Lalu anak menjawab "Di sup." Jenis pertanyaan dan jawaban ini pada prinsipnya bukanlah tahapan komunikasi dari pendekatan saintifik karena hal yang dikomunikasikan oleh anak bukanlah hasil pengamatan atau penalarannya. Jawaban anak sebagai bentuk komunikasi sebagai hasil mengingat-ingat pengalamannya tetapi bukan hasil menalar, menganalisa, atau mengevaluasi umbi kentang yang sedang mereka pelajari. Sebaiknya guru mengganti pertanyaan dengan pertanyaan yang membuat anak melakukan pengamatan lebih intensif maupun melakukan penalaran atas objek yang diamati. Contoh pertanyaan-pertanyaan untuk meprovokasi anak supaya melakukan pengamatan intensif antara lain "apa beda kentang yang sedang kamu pegang dengan kentang yang dipegang oleh teman di sebelahmu?", "apa rasa kentang yang sedang kamu pegang?", "hal-hal apa saja yang bisa kau lakukan dengan kentangmu?" Contoh pertanyaan untuk memprovokasi daya nalar anak antara lain "bisakah kita memakan kentang ini saat ini juga? Mengapa?", "bisakah kita menjadikan kentang ini sebagai pengganti bola? Mengapa?", dan seterusnya.

Selanjutnya, sama seperti kedua sekolah sebelumnya, anak juga tidak memiliki kesempatan untuk mengkomunikasikan hasil pengamatan dan hasil penalarannya karena guru tidak memberi kesempatan dan tidak menyediakan medianya. Sebagai contoh, jika anak diberi kesempatan untuk mengkomunikasikan jawaban dari pertanyaan "permainan apa saja yang bisa kulakukan dengan sebuah kentang?", maka mungkin anak akan mengekplorasi berbagai hal yang mereka bisa lakukan dengan kentang mereka dan kemudian menyampaikan hasil temuan mereka dalam bentuk tulisan, gambar, maupun hasil karya lainnya. 


\section{SIMPULAN DAN SARAN}

Dari ketiga sekolah yang diamati, satu sekolah memiliki alokasi waktu pembelajaran sains secara khusus dan dua sekolah lainnya tidak memiliki alokasi pembelajaran sains secara khusus. Kedua sekolah yang tidak memiliki mata pelajaran khusus sains mengintegrasikan sains melalui pendekatan saintifik yang mereka usung setiap hari sesuai tema pembelajaran. Hasil analisa penelitian menunjukkan bahwa ketiga sekolah belum menerapkan pendekatan sains yang baik dalam pembelajarannya.

Kedua sekolah yang mengimplementasikan pendekatan saintifik setiap harinya ternyata belum mampu mengimplementasikan pendekatan proses sains yang dapat mengomptimalkan keterampilan proses sains. Kedua sekolah sudah menggunakan benda nyata, tetapi guru belum mampu mengoptimalkan proses pengumpulan data pada benda nyata yang telah dihadirkan sebagai media pembelajaran. Demikian pula tahap menalar dan mengkomunikasikan tidak dapat optimal karena tahap sebelumnya (mengumpulkan data melalui pengamatan dan bertanya) tidak terlewati dengan optimal.

Kesimpulan pertama dari penelitian ini adalah bahwa pendekatan saintifik memiliki tahapantahapan yang harus dilalui dengan optimal supaya tahap selanjutnya dapat dilaksanakan dengan optimal pula. Sulit mengharapkan anak dapat memiliki tahap menalar yang baik jika anak tidak memiliki cukup data yang didapat dari tahap pengamatan dan bertanya. Demikian pula pengembangan keterampilan anak dalam tahap mengkomunikasikan juga sulit dioptimalkan jika anak tidak memiliki cukup data pengamatan dan hasil penalaran sebagai bahan komunikasi. Jika guru ingin anak-anak didiknya memiliki keterampilan proses sains yang baik, maka guru harus mampu mengoptimalkan tahap awal pendekatan saintifik: tahap pengumpulan data.

Kesimpulan penting kedua yang didapat dari penelitian ini adalah ada beberapa faktor kunci penting yang mempengaruhi kualitas tahap pelaksanaan pengumpulan data. Setidaknya ada tiga faktor kunci yang mempengaruhi kualitas proses sains (pendekatan saintifik) yaitu kecukupan bahan ajar, kecukupan waktu, dan pertanyaan guru. Faktor pertama adalah kecukupan benda nyata yang diusung menjadi materi pembelajaran. Material atau bahan yang cukup memberi akses anak untuk berinteraksi dengan material tersebut. Interaksi yang terjadi dapat mengaktivasi berbagai indra sensori anak: anak dapat meraba dan merasakan teksturnya, anak dapat menghidu, anak dapat merasakan rasanya, dan mendegar berbagai suara yang dihasilkan benda saat bermain-main dengan bahan ajar tersebut.

Faktor penting yang kedua adalah adanya waktu yang cukup bagi anak untuk berinteraksi dengan bahan ajar yang telah disediakan. Tanpa waktu yang cukup, anak tak punya kesempatan untuk merabai, merasakan, memainkan, dan mengeksplorasi bahan ajar tersebut.

Faktor penting yang ketiga adalah kemampuan guru kelas untuk membuat pertanyaan maupun instruksi yang dapat memprovokasi anak untuk melakukan proses pengamatan. Kadangkala dapat terjadi anak mendapat bahan ajar dan waktu yang cukup, tetapi anak tidak tahu apa yang mau ia lakukan terhadap bahan ajar yang ada di hadapannya. Saat itulah peran guru menjadi penting. Pertanyaaan maupun instruksi seperti "coba amati apakah ada yang menarik dari kentang yang ada di hadapanmu", "apa yang terjadi jika kamu gelindingkan kentang itu", "kentang siapa yang paling berat di kelas ini?",'”apa beda kentangmu dengan kentang di sebelahmu", dan lain sebagainya, mampu memprovokasi anak-anak yang bingung dan tidak tahu harus apa.

Dengan dua temuan penting tersebut, dapat dikatakan bahwa pendekatan saintifik yang dilakukan oleh ketiga lembaga PAUD belum optimal dalam membentuk keterampilan proses sains anak. Untuk membentuk keterampilan proses sains anak yang optimal, dibutuhkan benda nyata dalam pembelajaran yang jumlahnya memadai bagi murid, dibutuhkan waktu yang cukup untuk anak dapat mengamati dan mengesplorasi benda nyata tersebut, serta dibutuhkan pertanyaan guru yang dapat menuntun anak melakukan tahapan-tahapan pendekatan saintifik dengan optimal.

Saran bagi penelitian selanjutnya adalah untuk melihat implementasi pendekatan saintifik yang menerapkan semua kondisi yang menjadi temuan dalam penelitian ini. Disarankan peneliti selanjutnya untuk melakukan kajian ekploratif lebih dalam lagi apakah jika kecukupan bahan, kecukupan waktu, dan pertanyaan yang tepat telah dipersiapkan dengan baik, maka implementasi pendekatan saintifik di kelas menjadi lebih berkualitas. 
Implementasi Pendekatan Saintifik Sebagai Pembentuk Keterampilan Proses Sains Anak Usia Dini (Maria Melita Rahardjo)

\section{DAFTAR PUSTAKA}

Airlanda, G. (2019). Identifikasi pemahaman sains mahasiswa PGSD UKSW tentang pola makan sehari-hari berbasis home science process skill. Scholaria: Jurnal Pendidikan Dan Kebudayaan, 9(1), 93-102

Angkur, M. F. M. (2019). Penerapan pendekatan saintifik pada pendidikan anak usia dini. Jurnal Smart PAUD, 2(1), 37-42.

Duschl, R. A., Shouse, A. W., \& Schweingruber, H. A. (2008). What research says about K-8 science learning and teaching? PRINCIPAL-ARLINGTON-, 87(2), 16.

Early, D. M., Iruka, I. U., Ritchie, S., Barbarin, O. A., Winn, D. M. C., Crawford, G. M., et al. (2010). How do pre-kindergarteners spend their time? Gender, ethnicity, and income as predictors of experiences in pre-kindergarten classrooms. Early Childhood Research Quarterly, 25, 177-193

Eschach, H. And Fried, M.N. (2005). Should Science be Taught in Early Childhood? Journal of Science Education and Technology, 14 (3), 315-336.

Putri, C. E., Haenilah, E. Y., \& Surahman, M. (2017). Pembelajaran Ilmiah Bagi Anak Usia Dini. Jurnal Pendidikan Anak, 3(2).

Gerde, H.K., Schachter, R.E., \& Wasik, B.A. (2013). Using the scientific method to guide learning: An integrated approach to early childhood curriculum. Early Childhood Educ J, 41, 315-323.

Hanley, G. P., Tiger, J. H., Ingvarsson, E. T., \& Cammilleri, A. P. (2009). Influencing preschoolers' free-play activity preferences: An evaluation of satiation and embedded reinforcement. Journal of Applied Behavior Analysis, 42, 33-41.

Howitt, C., Upson, E., \& Lewis, S. (2011). It's a mystery! A case study of implementing forensic science in preschool as scientific inquiry. Australasian Journal of Early Childhood, 36, 45-55.

Inan, H. Z., Trundle, K. C., \& Kantor, R. (2010). Understanding natural sciences education in a Reggio Emilia-inspired preschool. Journal of Research in Science Teaching, 47, 1186-1208.

Kementrian Pendidikan dan Kebudayaan. (2014). Peraturan menteri pendidikan dan kebudayaan republik Indonesia nomor 146 tahun 2014 tentang kurikulum 2013 pendidikan anak usia dini.

Klarissa, N. W. E., Tirtayani, L. A., Psi, S., Psi, M., Wiyasa, I. K. N., \& Kes, M. (2018). Pengaruh Pendekatan Saintifik Terhadap Kemampuan Sains Permulaan Anak Kelompok B3 TK Sila Chandra I Batubulan Kecamatan Sukawati Tahun Ajaran 2017/2018. Jurnal Pendidikan Anak Usia Dini Undiksha, 6(1).

Moleong, L.J. (2009). Metode Penelitian Kualitatif. Bandung: Remaja Rosdakarya

Nayfeld, I., Brenneman, K., \& Gelman, R. (2011). Science in the classroom: Finding a balance between autonomous exploration and teacher-led instruction in preschool settings. Early Education \& Development, 22, 970-988.

Padilla, M. J. (1990). The science process skills. Research Matters-to the science Teacher, 9004.

Peterson, S. M., \& French, L. (2008). Supporting young children's explanations through inquiry science in preschool. Early Childhood Research Quarterly, 23, 395-408.

Putri, T.E., Mawardi, \& Diana. (2019). Penerapan metode demonstrasi dalam pembelajaran sains sederhana pada anak usia dini di pendidikan anak usia dini Citra Kartini Pontianak Kota. Jurnal Edukasi Pendidikan Anak Usia Dini, 5(2), 75-79.

Mirawati and Nugraha, R. (2017). Meningkatkan Keterampilan Proses Sains Anak Usia Dini Melalui Aktivitas Berkebun. Early Childhood: Jurnal Pendidikan, 1(1), 1-15.

Morrison, K. (2012) Integrate Science and Arts Process Skills in the Early Childhood Curriculum. Dimensions of Early Childhood, 40 (1), 31-38. 
Munastiwi, E. (2015). Implementasi Pendekatan Saintifik pada Pembelajaran Pendidikan Anak Usia Dini (PAUD). Al-Athfal\&58; Jurnal Pendidikan Anak, 1(2), 43-50.

Murtafiah. (2019). Upaya peningkatan pembelajaran sains pada anak usia dini melalui riset pengembangan metode Higher, Order, Thinking Skills (HOTS). Prosiding Seminar Nasional Pendidikan KALUNI, 2, 125-136.

Rahayu, E. F. (2015). Manajemen Pembelajaran dalam Rangka Pengembangan Kecerdasan Majemuk Peserta Didik. Manajemen Pendidikan, 24(5), 357-366

Rahmah. (2018). Persepsi guru tentang pembelajaran sains anak usia 5-6 tahun di Gugus II Melati Kecamatan Simpang Tiga Pekanbaru. KINDERGARTEN: Journal of Islamic Early Childhood Education, 1(2), 89-101.

Ravanis, K. (2017). Early Childhood Science Education: State of the Art and Perspectives. Journal of Baltic Science Education, 16 (3), 284-288.

Sanjaya, W. (2013). Penelitian pendidikan: Jenis, metode dan prosedur. Jakarta: Prenada Media Grup.

Seekda, S. And Fleer, M. (2014) Small Science: Infants and Toddlers Experiencing Science in Everyday Family Life. Res Sci Educ, 45, 445-464.

Sriningsih, N. N., Ardana, I. K., Tirtayani, L. A., Psi, S., \& Psi, M. (2018). Pengaruh Pendekatan Saintifik Terhadap Kemampuan Berpikir Logis Pada Anak Kelompok B PAUD Kumara Asri, Denpasar. Jurnal Pendidikan Anak Usia Dini Undiksha, 6(1).

Sugiyono. (2017). Metode penelitian kuantitatif, kualitatif, dan R\&D. Bandung: Alfabeta.

Suryana, D. (2017). Pembelajaran Tematik Terpadu Berbasis Pendekatan Saintifik Di Taman KanakKanak. JPUD-Jurnal Pendidikan Usia Dini, 11(1), 67-82.

$\mathrm{Tu}, \mathrm{T}$. (2006). Preschool science environment: What is available in a preschool classroom? Early Childhood Education Journal, 33, 245-251.

Utami, T. (2016). Penerapan pendekatan saintifik dalam upaya penanaman kompetensi inti anak usia dini di PAUD Terpadu AN-Nuur Sleman, Yogyakarta. Tesis Pascasarjana UIN Kalijaga: Yogyakarta.

Widodo, A., \& Pujiastuti, S. (2006). Profil pertanyaan guru dan siswa dalam pembelajaran sains. Jurnal pendidikan dan pembelajaran, 4(2), 139-148. 